\title{
PENGARUH LATIHAN TUCK JUMP DAN BARRIER TERHADAP POWER DAN KEKUATAN OTOT TUNGKAI
}

\author{
Saraswati Dharani Putri ${ }^{1}$, Oce Wiriawan ${ }^{2}$, Edy Mintarto ${ }^{3}$ \\ ${ }^{123}$ Jurusan Pendidikan Olahraga, Universitas Negeri Surabaya, Surabaya, Indonesia \\ *dharaniputri19@gmail.com
}

(Received: February 2019 / Revised: March 2019 / Accepted: March 2019)

\begin{abstract}
ABSTRAK: Penelitian ini bertujuan untuk menganalisis pengaruh yang diberikan oleh dua jenis latihan tuck jump dan barrier terhadap power dan kekuatan otot tungkai. Rancangan penelitian yang digunakan dalam penelitian ini yaitu rancangan penelitian Non Equivalent (pre test and post test) control group design. Kelompok pertama merupakan kelompok yang mendapatkan perlakuan berupa latihan barrier. Kelompok kedua merupakan kelompok yang mendapatkan perlakuan berupa latihan tuck jump kelompok ketiga adalah kelompok yang tidak mendapat perlakuan apapun. Terdapat tiga tahapan yang digunakan dalam penelitian ini, yaitu pre-tes, perlakuan, dan pos-tes. Waktu penelitian yang digunakan adalah selama enam Minggu. Syarat uji hipotesis adalah variansi dan homogen. Pada variable power otot tungkai memiliki signifkan 0,006 pada kelompok Barrier dan 0,001 pada Tuck jump. Kedua latihan juga memiliki perbedaan pengaruh terhadap power otot tungkai $(0,034)$ dan kekuatan otot tungkai $(0,031)$. Hasil penelitian ini memberikan kesimpulan bahwa latihan barrier dan tuck jump memberikan pengaruh, baik terhadap power otot tungkai maupun kekuatan otot tungkai. Pengaruh yang diberikan dari kedua jenis latihan juga berbeda. KATA KUNCI: Tuck Jump, Barrier, Power Otot Tungkai, Kekuatan Otot Tungkai.

ABSTRACTS: This study aimed to determine whether there was an influence given by two types of tuck jump and barrier exercises against power and leg muscle strength. This study used three groups consisting of 30 students in the implementation. The first group was treated as a barrier exercise. The second group was a group that received treatment in the form of tuck jump exercise. As well as the third group was a group that did not get any treatment. There were three stages used in this research, namely pre-test, treatment, and post-test. The study time used was for six weeks. Hypothesis testing requiremed are variance and homogeneity in leg muscle power variables having a significant 0.006 in the barrier group and 0.001 in the tuck jump group. Both exercise had different effects on leg muscle power 0.034 and leg muscle strength 0.031 . The results of this study concluded that barrier and tuck jump exercises had a significant effect on both leg muscle and leg muscle strength. The effects of both types of exercise were also differ significantly. KEYWORD: Tuck Jump, Barrier, Limb Muscle Power, Muscle Limb Strength.
\end{abstract}

\section{PENDAHULUAN}

Beberapa tahun terakhir dunia olahraga diinvestasi oleh beberapa produk terbaru tentang metode yang mampu meningkatkan performa fisik atlet. Banyak metode yang saling mengungkapkan metode mereka yang terbaik. Salah satu metode yang paling populer untuk meningkatkan kinerja fisik seorang atlet adalah metode latihan pliometrik. Latihan pliometrik telah lama dikenal sebagai latihan yang dapat meningkatkan power otot, lebih-lebih otot tungkai atau kaki (Komi,
1992). Dalam unsur kondisi fisik terdapat power yang merupakan salah satu unsur kondisi fisik yang sangat dibutuhkan oleh atlet yang sering melakukan gerakan eksplosif, sedangkan power merupakan hasil perkalian antara gaya (F) dan waktu (S). Penelitian ini peneliti menggunakan dua metode latihan plyometric, yaitu Tuck Jump dan Barrier. 


\section{METODE PENELITIAN}

$\begin{array}{llllll}\text { K1 } & \text { O1 } & ------ & \text { Xa } & ------ & \text { O2 } \\ \text { K2 } & \text { O3 } & ------ & \text { Xb } & ----- & \text { O4 } \\ \text { K3 } & \text { O5 } & ------ & \text { Xc } & ------ & \text { O6 }\end{array}$

Gambar 1. Rancangan Penelitian Non Equivalent (pre test and post test) control group design (Sriundy, 2015:201)

Kelompok ekperimen 1 diberi perlakuan $\left(\mathrm{X}_{\mathrm{a}) \text {, }}\right.$ yaitu: Tuck jump, kelompok eksperimen 2 diberi perlakuan $\left(\mathrm{X}_{\mathrm{b}}\right)$, yaitu: barier, , dan kelompok eksperimen 3 melakukan latihan konvensional $\left(X_{c}\right)$. Lama latihan 6 minggu selanjutnya dilakukan post test pada ketiga kelompok. Adapun hasil yang diperoleh peneliti dari hasil tes yaitu melakukan pengukuran sebelum pemberian perlakuan (pretest) terhadap sampel, yang meliputi kekuatan dan power otot tungkai, melakukan tes repetisi maksimal yang meliputi: Tuck jump dan Barier, yang hasilnya dipakai sebagai pertimbangan dalam menentukan progam latihan pada kedua kelompok sampel. Setelah itu data penelitian diperoleh dari hasil tes dan pengukuran sampel, untuk test kekuatan menggunakan instrument Leg Dynamometer dan untuk powet otot tungkai menggunakan Jump MD.

Hasil analisis deskriptif digunakan untuk memberikan gambaran hasil penelitian yang telah dilakukan. Adapun isi dari pemaparan deskriptif adalah membahas tentang data nilai jumlah data, nilai maksimal, nilai minimal, nilai rata rata dan nilai standart deviasi. Data hasil yang didapatkan melalui penelitian yang akan dideskripsikan yaitu dari data awal atau pre test dan data setelah penelitian atau post test. Analisis data deskriptif yang akan dilakukan menggunakan progam aplikasi SPSS 21.

\section{HASIL}

Tabel 1. Deskripsi Hasil Pre-test.

\begin{tabular}{clccccc}
\hline $\begin{array}{c}\text { Metod } \\
\text { e }\end{array}$ & Statistik & $\mathbf{N}$ & $\begin{array}{c}\text { Minimu } \\
\mathbf{m}\end{array}$ & $\begin{array}{c}\text { Maximu } \\
\mathbf{m}\end{array}$ & $\begin{array}{c}\text { Mea } \\
\mathbf{n}\end{array}$ & $\begin{array}{c}\text { Std. } \\
\text { Deviatio } \\
\mathbf{n}\end{array}$ \\
\hline \multirow{2}{*}{$\begin{array}{c}\text { Tuck } \\
\text { Jump }\end{array}$} & $\begin{array}{l}\text { Kekuata } \\
\mathrm{n}\end{array}$ & 10 & 80 & 205 & 131.6 & 40.7 \\
\cline { 2 - 7 } & Power & 10 & 358 & 995 & 619 & 172 \\
\hline \multirow{2}{*}{ Barier } & $\begin{array}{l}\text { Kekuata } \\
\mathrm{n}\end{array}$ & 10 & 90 & 201 & 131 & 37 \\
\cline { 2 - 7 } & Power & 10 & 468 & 799 & 612 & 115 \\
\hline \multirow{2}{*}{ Kontrol } & $\begin{array}{l}\text { Kekuata } \\
\mathrm{n}\end{array}$ & 10 & 87 & 200 & 132 & 39 \\
\cline { 2 - 7 } & power & 10 & 470 & 782 & 613 & 114 \\
\hline
\end{tabular}

Tabel 2. Deskripsi Hasil Pos-test.

\begin{tabular}{clccccc}
\hline $\begin{array}{c}\text { Metod } \\
\text { e }\end{array}$ & Statistik & $\mathbf{N}$ & $\begin{array}{c}\text { Minimu } \\
\mathbf{m}\end{array}$ & $\begin{array}{c}\text { Maximu } \\
\mathbf{m}\end{array}$ & $\begin{array}{c}\text { Mea } \\
\mathbf{n}\end{array}$ & $\begin{array}{c}\text { Std. } \\
\text { Deviatio } \\
\mathbf{n}\end{array}$ \\
\hline $\begin{array}{c}\text { Tuck } \\
\text { Jump }\end{array}$ & $\begin{array}{l}\text { Kekuata } \\
\mathrm{n}\end{array}$ & 10 & 89 & 198 & 137 & 39 \\
\cline { 2 - 7 } Power & 10 & 392 & 972 & 632 & 161 \\
\hline \multirow{2}{*}{ Barier } & $\begin{array}{l}\text { Kekuata } \\
\mathrm{n}\end{array}$ & 10 & 99 & 197 & 135 & 345 \\
\cline { 2 - 7 } & Power & 10 & 493 & 788 & 624 & 105 \\
\hline \multirow{2}{*}{ Kontrol } & $\begin{array}{l}\text { Kekuata } \\
\mathrm{n}\end{array}$ & 10 & 84 & 192 & 129 & 36 \\
\cline { 2 - 7 } & power & 10 & 463 & 758 & 608 & 105 \\
\hline \multirow{2}{*}{} & & & & & &
\end{tabular}

Dari data diatas didapatkan perubahan rerata data sebelum penelitian dan sesudah penelitian. Hal ini agar mudah dipahami maka akan digambarkan melalui grafik berikut ini :

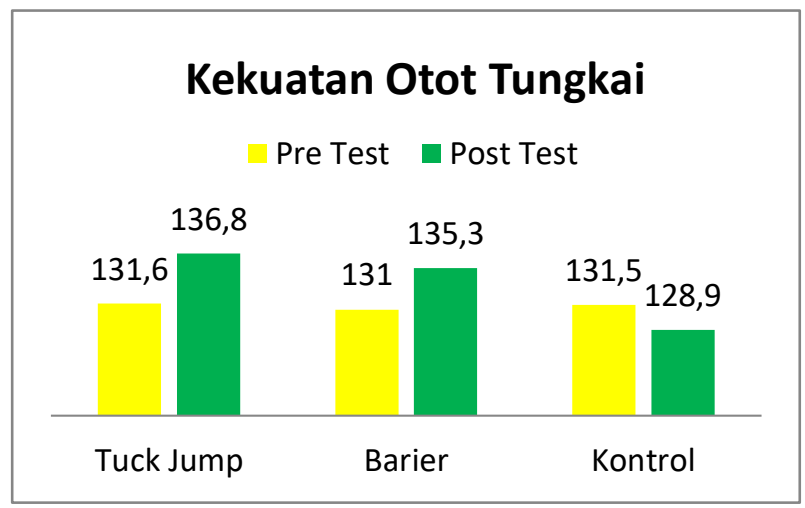

Grafik 1. Perubahan Rerata Komponen Fisik Kekuatan Otot Tungkai. 


\section{Power Otot Tungkai}

Pre Test $\square$ Post Test

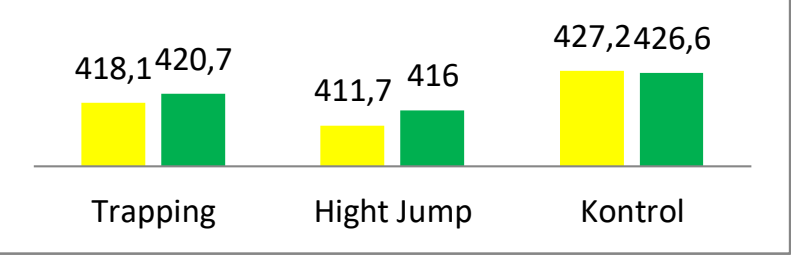

Grafik 2. Perubahan Rerata Komponen Fisik Power Otot Tungkai.

Uji Pair Test

Tabel 3. Hasil Paired Sample T Test Kelompok Tuck Jump.

\begin{tabular}{ccc}
\hline \multicolumn{3}{c}{ Paired Samples Test } \\
\hline \multicolumn{3}{c}{ Sig. (2- } \\
tailed) \\
\multirow{2}{*}{ Tuck Jump } & Kekuatan & 0,036 \\
& Power & 0,049 \\
\hline
\end{tabular}

Tabel 4. Hasil Paired Sample T Test Kelompok Barier.

\begin{tabular}{ccc}
\hline \multicolumn{2}{c}{ Paired Samples Test } \\
\hline \\
& Sig. & $(2-$ \\
& tailed) \\
& & 0,030 \\
Barier & Kekuatan & 0,036 \\
\hline
\end{tabular}

Tabel 4. Hasil Paired Sample T Test Kelompok Kontrol.

\begin{tabular}{ccc}
\hline \multicolumn{3}{c}{ Paired Samples Test } \\
\hline \multirow{3}{*}{ Kontrol } & Sig. (2- & tailed) \\
& Kekuatan & 0,334 \\
& Power & 0,328 \\
\hline
\end{tabular}

Uji Anova

Tabel 5. Hasil Perhitungan Anova One Way Anova.

\begin{tabular}{|c|c|c|c|}
\hline \multicolumn{4}{|c|}{ Anova } \\
\hline \multicolumn{2}{|c|}{ Kekuatan } & Sig. & Ket. \\
\hline Selisih & $\begin{array}{c}\text { Between } \\
\text { Groups }\end{array}$ & 0.031 & $\begin{array}{c}\mathrm{Ha} \\
\text { diterima } \\
\text { (Berbeda) }\end{array}$ \\
\hline \multicolumn{2}{|c|}{ Power } & Sig. & \\
\hline Selisih & $\begin{array}{c}\text { Between } \\
\text { Groups }\end{array}$ & 0.034 & $\begin{array}{c}\mathrm{Ha} \\
\text { diterima } \\
\text { (Berbeda) }\end{array}$ \\
\hline
\end{tabular}

Berdasarkan tabel diatas, variabel kekuatan dan power otot tungkai memiliki nilai sig. $<0.05$ dengan arti menolak $\mathrm{Ha}$, sehingga dapat disimpulkan bahwa terdapat perbedaan antara ketiga kelompok terhadap kekuatan dan power otot tungkai.

Setelah dapat dipastikan bahwa terdapat perbedaan yang signifikan antara ketiga jenis latihan, maka analisis dilanjutkan dengan uji lanjut Post Hoc Comparisons yang digunakan untuk mengetahui kombinasi perbedaan antara ketiga jenis latihan. Pada variabel kekuatan dan power, kombinasi perbedaan yang signifikan terjadi antara latihan tuck jump dan barier dengan kontrol dengan nilai sig. $<0.05$.

\section{PEMBAHASAN}

Hasil perlakuan dengan menggunakan latihan tuck jump didapatkan hasil bahwa latihan tersebut memiliki pengaruh terhadap power dan kekuatan otot tungkai. Dasar pengambilan kesimpulan tersebut adalah nilai signifikansi yang diperoleh power otot tungkai adalah sebesar 0,036 . Sedangkan signifikansi yang diperoleh kekuatan otot tungkai adalah 0,049. Tuck jump merupakan salah satu bentuk latihan untuk mengembangkan kekuatan vertikal yang sifatnya mengembangkan kekuatan otot tungkai dan otot perut di dalam titik berat badan. Fokus perkenaan otot yang dilatih adalah fleksor pinggul dan paha, gastrocnemius, gluteals, quadriceps dan hamstring (Furqon \& Doowes, 2002).

\section{SIMPULAN DAN REKOMENDASI}

Dalam peningkatan kinerja fisik kekuatan dan power otot tungkai dapat menggunakan latihan plyometric dengan metode latihan tuck jump.

Peningkatan kinerja fisik kekuatan dan power otot tungkai dapat menggunakan latihan plyometric dengan metode latihan barier. 
Terdapat perbedaan hasil dari penelitian yang dilakukan antara tiga kelompok terhadap peningkatan kekuatan dan power otot tungkai. Dalam peningkatan kekuatan otot tungkai lebih signifikan jika menggunakan metode tuck jump dan dalam peningkatan power otot tungkai lebih signifikan menggunakan metode tuck jump.

\section{REFERENSI}

Bosco, C., Luhtanen, P., \& Komi, P. V. (1983).

Bompa, T., \& Buzzichelli, C. (2015). Periodization Training for Sports, 3E. Human kinetics.

Furqon. (2002). Statistika terapan untuk penelitian.Bandung:Alfabeta.

Katno, K. (2015). Pengaruh Latihan Knee Tuck Jump dan Barier Hops terhadap Kualitas Tendangan Bola Lambug Jauh (Doctoral dissertation, Univrsitas Muhamadiyah Surakarta)

Komi, P.V. \& Kim, D.H. (1992) Effects of power training on neuromuscular performance and mechanical efficiency. Scandinavian Journal of Medicine and Science in Sports (in press).

Mahardika, I Made Sriundy. 2015. Metodelogi Penelitian. Surabaya: Unesa University Press.

McGinnis, P. (2013). Biomechanics of sport and exercise. Human Kinetics.

Miller, R. M., \& Bemben, M. G. (2017). Lower limb muscular power and its relationship to hitting performance measures in collegiate baseball and softball athletes. Journal of Sport and Human Performance, 5(2)

Myer, G. D., Ford, K. R., \& Hewett, T. E. (2008). Tuck jump assessment for reducing anterior cruciate ligament injury risk. Athletic Therapy Today, 13(5), 39-44.

Radcliffe, J. C., \& Farentinos, R. C. (1985). Plyometrics: Explosive power training. Human Kinetics.

Sankey, S. P., Jones, P. A., \& Bampouras, T. (2008). Effects of two plyometric training programmes of different intensity on vertical jump performance in high school athletes. Serbian journal of sports sciences,
2(4), 123-130. Shanker A., Shankar A., Shankar A., 2008. Ayurveda a Boon for Epileptics. J Homeop Ayurv Med: 2-4 Sukadiyanto. (2011). Pengantar teori dan metodelogi melatih fisik. Bandung:CV. Lubuk Agung 